\title{
Sea grapes extract improves blood glucose, total cholesterol, and PGC-1a in rats fed on cholesterol- and fat-enriched diet
}

\section{[version 1; peer review: 1 approved with reservations]}

\author{
Mury Kuswari1', Fahrul Nurkolis (iD), Nelly Mayulu (iD)3, Faisal Maulana Ibrahim (Di)4, \\ Nurpudji Astuti Taslim (D), Defny Silvia Wewengkang (D6), Nindy Sabrina7, \\ Ghafur Rasyid Arifin ${ }^{8}$, Keren Esther Kristina Mantik ${ }^{3}$, Muhammad Rahimi Bahar ${ }^{9}$, \\ Najda Rifqiyati², Ronald Rompies ${ }^{9}$, Piko Satria Augusta10, \\ Happy Kurnia Permatasari (iD10
}

\footnotetext{
${ }^{1}$ Nutrition, Universitas Esa Unggul, Jakarta, Jakarta, 11510, Indonesia

${ }^{2}$ Biological Sciences, State Islamic University of Sunan Kalijaga (UIN Sunan Kalijaga Yogyakarta), Yogyakarta, Yogyakarta, 55281, Indonesia

${ }^{3}$ Nutrition, Sam Ratulangi University, Manado, North Sulawesi, 95115, Indonesia

${ }^{4}$ Pharmaceutical Analysis and Medicinal Chemistry, Universitas Padjajaran, Sumedang, West Java, 45363, Indonesia

${ }^{5}$ Nutritional Sciences, Hasanuddin University, Makassar, South Sulawesi, 90245, Indonesia

${ }^{6}$ Pharmacy, Sam Ratulangi University, Manado, North Sulawesi, 95115, Indonesia

${ }^{7}$ Nutrition, Sahid University of Jakarta, South Jakarta, Jakarta, 12870, Indonesia

8 Medicine, University of Indonesia, Depok, West Java, 16424, Indonesia

${ }^{9}$ Pediatrics, Sam Ratulangi University, Manado, North Sulawesi, 95115, Indonesia

${ }^{10}$ Medicine, Brawijaya University, Malang, East Java, 65145, Indonesia
}

V1 First published: 02 Aug 2021, 10:718

https://doi.org/10.12688/f1000research.54952.1

Latest published: 13 Sep 2021, 10:718

https://doi.org/10.12688/f1000research.54952.2

\section{Abstract}

Background: Sea grapes or Caulerpa racemosa have a lot of phytochemical content, especially unsaturated fatty acids that are beneficial for health. This study aims to evaluate the effects of sea grapes extract on blood glucose levels, total cholesterol-, and Peroxisome proliferator-activated receptor-gamma coactivator (PGC)1a in male Wistar rats, which were given per-oral (p.o.) cholesteroland carbohydrates fat-enriched diets (CFED). Methods: Forty male Wistar albino rats weighing between $200-250 \mathrm{~g}$ were used for this study. Animals were randomly distributed into four groups of ten animals each. Group A served as control (received standard dry pellet diet). Rats in group B were fed on CFED for 4 weeks. Groups C and D were fed on CFED and were administered 150 and $450 \mathrm{mg} / \mathrm{kg}$ of sea grapes extract (p.o.), respectively. Results: Group $\mathrm{C}$ rats indicated a blood glucose reduction and an increase in PGC-1 a serum, in comparison to group $D(p<0.05)$. There were no significant differences between group $C$ and $D$ in blood cholesterol reduction (high dose of the extract did not have significant effects) $(p=0.222)$, and both groups

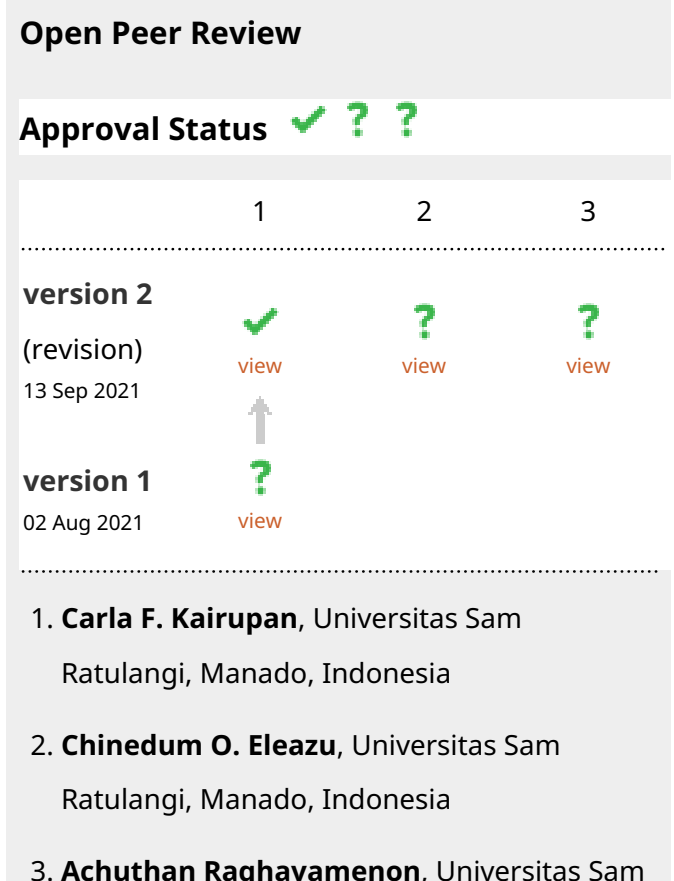

3. Achuthan Raghavamenon, Universitas Sam 
had the same effect in lowering total cholesterol in rats. Conclusion: Sea grapes extract is proven to improve blood glucose, total cholesterol, and PGC-1 a levels in rats fed with CFED.

\section{Keywords}

Caulerpa racemosa extract, blood glucose, total cholesterol, PGC-1a, functional food
Ratulangi, Manado, Indonesia

Any reports and responses or comments on the article can be found at the end of the article.

Corresponding authors: Mury Kuswari (mury@esaunggul.ac.id), Fahrul Nurkolis (20106040012@student.uin-suka.ac.id), Happy Kurnia Permatasari (happykp@ub.ac.id)

Author roles: Kuswari M: Conceptualization, Formal Analysis, Writing - Original Draft Preparation; Nurkolis F: Conceptualization, Formal Analysis, Investigation, Project Administration, Visualization, Writing - Original Draft Preparation; Mayulu N: Supervision, Validation, Writing - Review \& Editing; Ibrahim FM: Formal Analysis, Writing - Original Draft Preparation; Taslim NA: Formal Analysis, Supervision, Validation, Writing - Review \& Editing; Wewengkang DS: Project Administration, Supervision, Validation, Writing - Review \& Editing; Sabrina N: Supervision, Writing - Review \& Editing; Arifin GR: Data Curation, Writing - Review \& Editing; Mantik KEK: Investigation, Project Administration, Writing - Review \& Editing; Bahar MR: Writing - Review \& Editing; Rifqiyati N: Supervision, Writing - Review \& Editing; Rompies R: Writing - Review \& Editing; Augusta PS: Investigation, Writing - Original Draft Preparation; Permatasari HK: Supervision, Writing - Original Draft Preparation, Writing - Review \& Editing

Competing interests: No competing interests were disclosed.

Grant information: The author(s) declared that no grants were involved in supporting this work.

Copyright: ( 2021 Kuswari $\mathrm{M}$ et al. This is an open access article distributed under the terms of the Creative Commons Attribution License, which permits unrestricted use, distribution, and reproduction in any medium, provided the original work is properly cited.

How to cite this article: Kuswari M, Nurkolis F, Mayulu N et al. Sea grapes extract improves blood glucose, total cholesterol, and PGC-1 $\alpha$ in rats fed on cholesterol- and fat-enriched diet [version 1; peer review: 1 approved with reservations] F1000Research 2021, 10:718 https://doi.org/10.12688/f1000research.54952.1

First published: 02 Aug 2021, 10:718 https://doi.org/10.12688/f1000research.54952.1 


\section{Introduction}

Reactive Oxygen Species (ROS) are the amounts of reactive molecules and free radicals derived from oxygen in a molecule (i.e., superoxide, peroxide, hydrogen peroxide, hydroxyl radical, etc.) (Sies \& Jones, 2020). Oxygen-based radicals are produced as a byproduct in the mitochondrial electron transport at the aerobic respiration performed by oxidoreductase enzymes and metal-catalyzed oxidation. A recent study has shown that ROS has a role in cell apoptosis that leads to organ dysfunction (Pizzino et al., 2017).

Peroxisome proliferator-activated receptor-gamma coactivator (PGC)-1 $\alpha$ is a transcription coactivator that regulates the genes involved in energy metabolism. It is the main regulator of mitochondrial biogenesis (Liang \&Ward, 2006). PGC-1 $\alpha$ stimulates mitochondrial biogenesis and encourages the remodeling of muscle tissue to a fiber-type composition that is metabolically more oxidative and less glycolytic in nature, and it participates in the regulation of both carbohydrate and lipid metabolism (Puigserver \&Spiegelman, 2003; S. Yang et al., 2020).

The ability of cell defense against ROS has been associated with aging and contributes to the increased oxidative stress state. This condition can disturb the enzyme activity, especially through the reversible oxidative reaction at the thiol functional group at the side chain of the enzyme structures (Birben et al., 2012). This can lead to the alteration of biomolecule structure and integrity, and enzyme dysfunction (Freitas et al., 2016). As a result, insulin resistance and Type 2 Diabetes can development (Facchini et al., 2001; Meigs et al., 2003). Additionally, the effect of aging on changes in liver mass can increase serum Low-Density Lipoprotein (LDL)-cholesterol level, due to the hepatocytes cell death caused by oxidative stress (Anantharaju et al., 2002; Miller, 1984). Hence, effective control of ROS levels is essential. The aging population tends to have a higher prevalence of chronic disease, thus there is a demand for health-improving foods (Park, 2013). The consumption and production of high-antioxidant as functional foods in recent years are popular due to their capability of reducing Reactive Oxygen Species (ROS), as well as having an impact on several aging and chronic related diseases (Park, 2013; Park et al., 2004). However, there are some challenges that are associated with the utilization of functional food. For example, specific functional foods need to be consumed in high concentrations in order to be biologically effective, therefore, this would require the nutritional facts such as the daily dose of the bioactive compound in each serving size to be determined (Kang et al., 2011). Preliminary studies are needed to determine which bioactive compound is the most beneficial, and what is the quantitative-activity relationship between the bioactive compounds contained in functional foods.

Sea grapes (Caulerpa racemosa) or lawi-lawi (Indonesia-local terminology) is a species of editable green alga, seaweed in the Caulerpaceae family found in waters surrounding Sulawesi (Pakki et al., 2020). Sea grapes are harvested intensively as they are an important source of macronutrients and micronutrients, especially in East and South-East Asia (grown commercially in ponds and consumed in the Philippines, Indonesia and Vietnam) as a major part of the traditional diet (Chen et al., 2019). Some studies showed that sea grapes contains several bioactive components, such as protein, polysaccharides, polyphenol, flavonoids, and antioxidants (P. Yang et al., 2015; Yep et al., 2019; Taslim \& Fahrul, 2021). Moreover, sea grapes have a high antioxidant level, and they have the potential to act as functional food or nutraceuticals (Tanna et al., 2020; Yep et al., 2019; Nurkolis et al., 2021). The extract of sea grapes can reduce glucose level, aspartate aminotransferase (AST), alanine aminotransferase (ATL). Moreover, it appears to have a hepatoprotective activity in diabetic rats (Qudus B Aroyehun et al., 2020). Therefore, this study aims to evaluate the effects of Sea grapes extract on blood glucose levels, total cholesterol, and PGC-1 $\alpha$ in male Wistar rats on cholesterol- and fat-enriched diets (CFED).

\section{Methods}

This in vivo study was conducted at the pharmacological laboratory, faculty of mathematics and natural sciences, Sam Ratulangi University.

\section{Collection and preparation of plant material}

Fresh sea grapes (Caulerpa racemosa) was collected from the shallow section (5-10 meters from the sea surface) of the Mantehage seawater, North Sulawesi, Indonesia. The botanical identification and authentication were confirmed at the department of pharmacology, faculty of mathematics and natural sciences, Sam Ratulangi University, Indonesia. The specimens were collected for feature references. The sea grapes were rinsed thoroughly with water, air-dried at room temperature and in an $40^{\circ} \mathrm{C}$ oven, then powdered by an electric mill.

\section{Preparation of sea grapes extracts}

Crude powder (one kg) was macerated in $96 \%$ ethanol for 72 hours with each extraction performed in triplicates, which resulted in $34 \%$ yield. The crude extracts were filtered by Whatman 41 filter paper. The total filtrate was concentrated and evaporated at $40^{\circ} \mathrm{C}$ with a rotary evaporator RV 8 IKA under reduced pressure (100 millibar) for 90 minutes, and 
evaporated in an $40^{\circ} \mathrm{C}$ oven to produce a thick extract. The extract was stored in a refrigerator at $10^{\circ} \mathrm{C}$ until used in the study.

\section{Animal handling and ethical approval}

All experimental rats were kept on standardized free access of feed and ad libitum of water. The study was conducted in the Laboratory of Pharmacology, Faculty of Mathematics and Natural Sciences, Sam Ratulangi University, Makassar, Indonesia. Forty male Wistar albino rats (Rattus norvegicus) (4-5 weeks) weighing between 200 - $250 \mathrm{~g}$ were obtained from the Laboratory Animals Farming Makassar, Indonesia, and transported to the research site. The animals were grouped and housed in cages and maintained under standard laboratory conditions (temperature: $27 \pm 2^{\circ} \mathrm{C}$ ), with light and dark cycles (12/12 hours). The rats were acclimatized to laboratory conditions for 10 days before the commencement of the experiment. The research protocol (use of experimental animals) refers to the Declaration of Helsinki. The Council for International Organizations of Medical Sciences (CIOMS) has approved the application of ethical health research protocols online (http://sim-epk.keppkn.kemkes.go.id) RSUP Prof. Dr. RD. Kandou, Manado with No. 086/EC/KEPKKANDOU/VI/2021. Additionally, all experimental procedures were carried out according to the Institutional Animal Care and Usage Committee (ARRIVE guidelines) (Nurkolis et al., 2021).

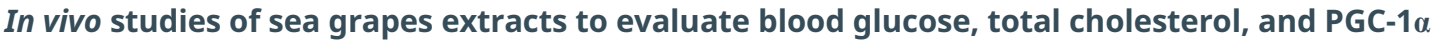 levels CFED production}

Carbohydrates fat-enriched diets (CFED) is a standard mouse food that comes with $1 \%$ colic acid, $2 \%$ pure cholesterol powder, $20 \%$ fat (animal source/pork oil), and 2\% corn oil. Additional components are subtly added to the standard CFED and homogenized into a dough with the addition of $1000 \mathrm{~mL}$ of aqua dest. Small pellets are cut and left to dry at room temperature in sterile conditions. CFED is prepared weekly and stored at $4{ }^{\circ} \mathrm{C}$ until used to reduce oxidation. CFED consists of carbohydrate $(43.57 \%)$, coarse protein $(12.38 \%)$, coarse fiber $(4.73 \%)$, coarse fat $(3.17 \%)$, cholesterol (2\%), colic acid (1\%), animal fat (20\%), corn oil (2\%), total ash (4.3\%), and moisture (6.85\%). Compared to a normal diet that contains $58.1 \%$ carbohydrates, $16.51 \%$ coarse protein, and $0 \%$ animal fat, all the other components such as corn oil, cholesterol, and folic acid, were not significantly changed. CFED production guideline was carried out as previously described (Harb et al., 2018).

\section{Sea grapes extract administration scheme}

Wistar albino rats were randomly distributed into four groups of ten animals each. Group A served as control (received standard dry pellet diet). Rats in group B were fed on CFED for 4 weeks. Rats in groups C and D were fed on CFED and were given 150 and $450 \mathrm{mg} / \mathrm{kg}$ Body Weight (BW) of sea grapes extract, respectively, for 4 weeks. CFED and extract of sea grapes were administered by oral gavage.

\section{Sample collection}

Throughout the experiment, all the efforts were made to minimize the pain and distress of the experimental animals. For this purpose after four weeks of extract treatment, rats were kept fasted overnight and given euthanasia under ketamine anesthesia. $2.5 \mathrm{~mL}$ of blood samples were collected from the muscle tissue and kept in dry and clean tubes without addition of anticoagulants (Tiger-top tube), to allow clotting at room temperature. The samples were then centrifuged for 20 minutes at $3000 \mathrm{rpm}$. Finally, the sera were collected for the blood glucose, total cholesterol, and PGC-1 $\alpha$ analysis.

\section{Biomedical analysis of blood sample}

Blood glucose and cholesterol levels were assayed using COBAS Integra ${ }^{\circledR} 400$ plus analyzer (Roche) (See underlying data) (Nurkolis, 2021). Samples were washed with Phosphate Buffered Saline (PBS, pH 7.4) 1\% until the liquid runs clear. The samples were centrifuged at $3000 \mathrm{rpm}$ for 20 minutes to obtain pellets and supernatant. The supernatant is taken for the PGC-1 $\alpha$ examination (See underlying data) (Nurkolis, 2021). The concentration of PGC-1 $\alpha$ was measured by using mouse PGC-1 $\alpha$ ELISA Kit (Sunlong Biotech Co., Ltd, \# MBS288117).

\section{Data management and analysis}

The data were statistically analyzed with the use of the MANOVA/Multivariate ANOVA test. The Levene's test was used to determine which posthoc tests should be conducted. In cases where the Levene's test p-value was $<0.05$ Games-Howell test (equal variances not assumed), and for p-value $>0.05$ Bonferroni test (equal variances assumed) was used. Statistical analyses were performed by using SPPS 26.0 for the Windows version.

\section{Results}

The Levene's Homogeneity test shows that the p-value for glucose and PGC- $1 \alpha$ are $<0.05$, therefore equal variance cannot be assumed, while equal variances can be assumed for cholesterol as the p-value is $>0.05$. 
The results indicate that blood glucose significantly increased in group B, compared to group A $(\mathrm{p}<0.05)($ Table 2$)$. Blood glucose significantly decreased in both groups $\mathrm{C}$ and $\mathrm{D}(\mathrm{p}<0.05)$. The effect of sea grapes administration as much as $150 \mathrm{mg} / \mathrm{kg} \mathrm{BW}$ is more effective than the sea grapes $450 \mathrm{mg} / \mathrm{kg} \mathrm{BW}$, in significantly decreasing blood glucose in rats $(\mathrm{p}<0.05)$.

As expected the rats in group B had significantly increased blood cholesterol levels compared to group A (p < 0.05). In both groups $A$ and $B(p<0.05)$, blood cholesterol significantly decreased in rats given CFED + sea grapes extract $150 \mathrm{mg} / \mathrm{kg} \mathrm{BW}$, and CFED treatment + sea grapes extract $450 \mathrm{mg} / \mathrm{kg} \mathrm{BW}$. There was no significant difference between the CFED treatment group $+150 \mathrm{mg} / \mathrm{kg} \mathrm{BW}$ sea grapes extract, and the CFED treatment group $+450 \mathrm{mg} / \mathrm{kg} \mathrm{BW}$ sea grapes extract, in reducing blood cholesterol (high dose of the extract did not result in significant effects $(\mathrm{p}>0.05)$ ).

Group B had a significantly decreased PGC- $1 \alpha$ serum concentration. PGC- $1 \alpha$ serum concentrations significantly increased in group $\mathrm{C}$, as well in group $\mathrm{D}$, compared to groups $\mathrm{A}$ and $\mathrm{B}$. The effect of sea grapes administration as much

Table 1. Statistical interpretations based on homogeneity test.

\begin{tabular}{|c|c|c|c|c|c|}
\hline & & $\mathbf{F}$ & df1 & df2 & P-value \\
\hline \multirow[t]{4}{*}{ Glucose } & Mean & 10.495 & 3 & 36 & $.000 *$ \\
\hline & Median & 7.105 & 3 & 36 & $.001 *$ \\
\hline & Median (adjusted df) & 7.105 & 3 & 19.296 & $.002 *$ \\
\hline & Trimmed mean & 10.205 & 3 & 36 & $.000 *$ \\
\hline \multirow[t]{4}{*}{ Cholesterol } & Mean & 1.957 & 3 & 36 & .138 \\
\hline & Median & 1.741 & 3 & 36 & .176 \\
\hline & Median (adjusted df) & 1.741 & 3 & 23.800 & .186 \\
\hline & Trimmed mean & 1.853 & 3 & 36 & .155 \\
\hline \multirow[t]{4}{*}{ PGC- $1 \alpha$} & Mean & 9.042 & 3 & 36 & $.000 *$ \\
\hline & Median & 6.290 & 3 & 36 & $.002 *$ \\
\hline & Median (adjusted df) & 6.290 & 3 & 29.106 & $.002 *$ \\
\hline & Based on trimmed mean & 8.938 & 3 & 36 & $.000 *$ \\
\hline
\end{tabular}

F, Levene's Test; DF, Degrees of Freedom.

*Represents p-value $<0.05, \mathrm{CI}: 95 \%$.

Table 2. The low dose of sea grapes is more effective in significantly reducing blood glucose.

\begin{tabular}{|l|l|l|l|}
\hline & Diet & Mean & P-value \\
\hline Group A & CFED & -15.3880 & $.000^{*}$ \\
\hline & CFED + Sea grapes $150 \mathrm{mg} / \mathrm{kgBW}$ & 5.9500 & $.000^{*}$ \\
\hline & CFED + Sea grapes $450 \mathrm{mg} / \mathrm{kgBW}$ & $.001^{*}$ \\
\hline Group B & Control & 2.8900 & $.000^{*}$ \\
\hline & CFED + Sea grapes $150 \mathrm{mg} / \mathrm{kgBW}$ & 15.3880 & $.000^{*}$ \\
\hline Group C & CFED + Sea grapes $450 \mathrm{mg} / \mathrm{kgBW}$ & 21.3380 & $.000^{*}$ \\
\hline Group D & Control & 18.2780 & $.000^{*}$ \\
\hline & CFED & -5.9500 & $.000^{*}$ \\
\hline & CFED + Sea grapes $450 \mathrm{mg} / \mathrm{kgBW}$ & -21.3380 & $.003^{*}$ \\
\hline & Control & -3.0600 & $.001^{*}$ \\
\hline & CFED & -2.8900 & $.000^{*}$ \\
\hline
\end{tabular}

${ }^{*}$ Represents p-value $<0.05$, CI: $95 \%$. 
as $150 \mathrm{mg} / \mathrm{kg} \mathrm{BW}$ is more effective than that of sea grapes $450 \mathrm{mg} / \mathrm{kg} \mathrm{BW}$, in the significant increase of PGC-1 $\alpha$ serum in rats.

\section{Discussion}

This study showed that the supplementation of sea grapes extract managed to lower blood glucose and serum cholesterol significantly in rats that were given cholesterol- and fat-enriched diets (Figure 1). Although compared to the control group, rats that were given cholesterol- and fat-enriched diets with sea grapes extract had lower levels of blood cholesterol and blood glucose.

The Results of this study indicate that sea grapes have the capability of reducing blood glucose levels (Table 2). Similarly, Aroyehun et al., have shown that sea grapes have antidiabetic activity. The plasma analysis in this study has also indicated that the sea grapes treated group had a significant decrease $(\mathrm{p}<0.05)$ in their blood glucose levels compared to the untreated diabetic group (Qudus B Aroyehun et al., 2020). Sea grapes extract-treated group demonstrated similar efficacy in lowering blood glucose as Metformin (Qudus B Aroyehun et al., 2020), hence, sea grapes may have an hypoglycaemic effect. A hyperglycaemic state may induce oxidative stress that could be detrimental to insulin-sensitive tissues such as the liver, which may cause damage to the organ (Bugianesi 2005; Manna 2010; Palsamy 2010).

This study showed that sea grapes reduce hyperlipidemia in rats, however this is not in line with the findings by Aroyehun et al., (Qudus B Aroyehun et al., 2020), which states that sea grapes extract has little to no effect on the cholesterol level of induced diabetic rats. In addition, the effect of lower doses of the extract $(150 \mathrm{mg} / \mathrm{kg} \mathrm{BW})$ was better in lowering blood cholesterol than higher doses of sea grapes extract ( $450 \mathrm{mg} / \mathrm{kg} \mathrm{BW}$ ) (Figure 1, Table 3). This can be due to the saturated fatty acids content, especially palmitic acid, which dominates the composition of fatty acids, comprising $80 \%$ of the total fat in sea grapes (Qudus B Aroyehun et al., 2020). Studies have shown that palmitate acid may raise total cholesterol levels, specifically LDL-cholesterol levels (Clandinin et al. 2000; Mensink, 2013).

Levels of PGC-1 $\alpha$ in rats significantly decreased after being given a CFED diet compared to the control group (Figure 1, Table 4). However, PGC-1 $\alpha$ levels increased significantly in rats given sea grapes extract, even when compared to the control group. This suggests that PGC-1 $\alpha$, which is one of the major elements in mitochondrial biogenesis, is enhanced by the sea grapes extract. Perhaps the content of flavonoids as well as phenols in sea grapes extract can cause this effect. One study has shown that flavonoid supplementation increases the performance in endurance activities via an increase in expression of PGC- $1 \alpha$ as the "master regulator" of biogenesis and skeletal muscle angiogenesis (Khani et al. 2017). In

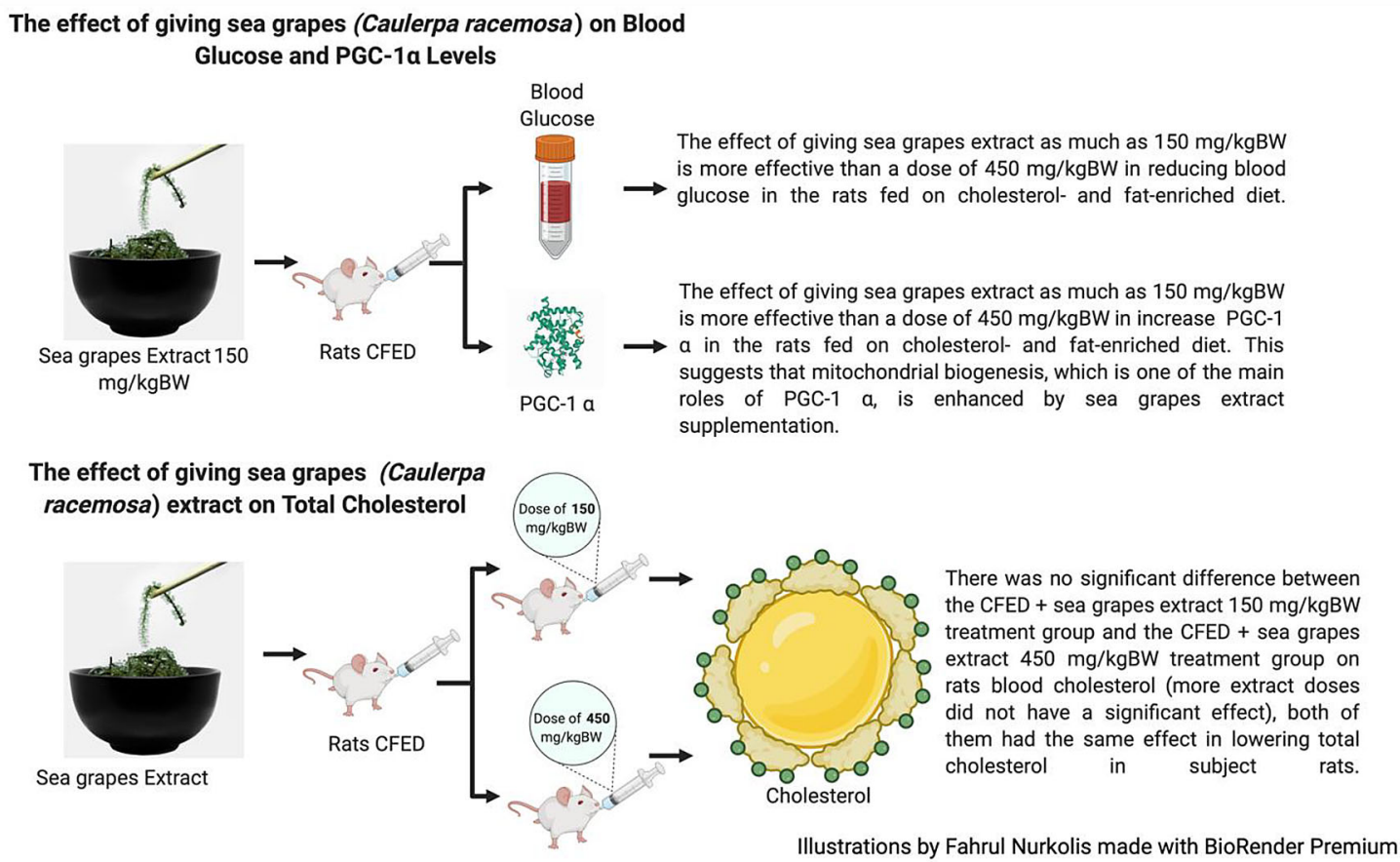

Figure 1. Effects of sea grapes extract on subject rats. 
Table 3. Both doses of sea grapes extract significantly reduce blood cholesterol.

\begin{tabular}{|c|c|c|c|}
\hline & Diet & Mean & P-value \\
\hline \multirow[t]{3}{*}{ Group A } & CFED & -22.1100 & $.000 *$ \\
\hline & CFED + Sea grapes 150 mg/kgBW & 12.0600 & $.000 *$ \\
\hline & CFED + Sea grapes 450 mg/kgBW & 8.0200 & $.001 *$ \\
\hline \multirow[t]{3}{*}{ Group B } & Control & 22.1100 & $.000 *$ \\
\hline & CFED + Sea grapes 150 mg/kgBW & 34.1700 & $.000 *$ \\
\hline & CFED + Sea grapes 450 mg/kgBW & 30.1300 & $.000 *$ \\
\hline \multirow[t]{3}{*}{ Group C } & Control & -12.0600 & $.000 *$ \\
\hline & CFED & -34.1700 & $.000^{*}$ \\
\hline & CFED + Sea grapes 450 mg/kgBW & -4.0400 & .222 \\
\hline \multirow[t]{3}{*}{ Group D } & Control & -8.0200 & $.001 *$ \\
\hline & CFED & -30.1300 & $.000^{*}$ \\
\hline & CFED + Sea grapes 150 mg/kgBW & 3.0600 & $.003^{*}$ \\
\hline
\end{tabular}

${ }^{*}$ Represents p-value $<0.05$, CI: $95 \%$.

Table 4. The low dose of sea grapes is more effective in significantly reducing PGC- $1 \alpha$.

\begin{tabular}{|l|l|l|l|}
\hline & Diet & Mean & P-value \\
\hline Group A & CFED & 20.9200 & $.000^{*}$ \\
\hline & CFED + Sea grapes $150 \mathrm{mg} / \mathrm{kgBW}$ & -19.3500 & $.000^{*}$ \\
\hline & CFED + Sea grapes $450 \mathrm{mg} / \mathrm{kgBW}$ & -14.4200 & $.000^{*}$ \\
\hline Group B & Control & -20.9200 & $.000^{*}$ \\
\hline Group C & CFED + Sea grapes $150 \mathrm{mg} / \mathrm{kgBW}$ & -40.2700 & $.000^{*}$ \\
\hline CFED + Sea grapes $450 \mathrm{mg} / \mathrm{kgBW}$ & -35.3400 & $.000^{*}$ \\
\hline Group D & Control & 19.3500 & $.000^{*}$ \\
\hline & CFED & 40.2700 & $.000^{*}$ \\
\hline & CFED + Sea grapes $450 \mathrm{mg} / \mathrm{kgBW}$ & 4.9300 & $.000^{*}$ \\
\hline & Control & 14.4200 & $.000^{*}$ \\
\hline CFED & 35.3400 & $.000^{*}$ \\
\hline
\end{tabular}

${ }^{*}$ Represents p-value $<0.05$, CI: $95 \%$.

addition, other studies have also shown that antioxidant compounds can upregulate PGC-1 $\alpha$ target genes, which not only play a role in preventing oxidative damage, but also reduce mitochondrial ROS levels, ensure mitochondrial integrity during cell differentiation (Beldelli et al. 2014), as well as avoiding the cytotoxic effects of ROS accumulation (St-Pierre et al. 2006).

\section{Conclusion}

Sea grapes extract is proven to improve blood glucose levels, total cholesterol, and PGC-1 $\alpha$ in rats fed with cholesteroland fat-enriched diets. The results of this study can be used as a reference for clinical trials to further research the beneficial effects of sea grapes for human consumption. However, it is necessary to do the same research with parameters other than blood sugar, cholesterol and pgc-1a, to expand its metabolic scope.

\section{Data availability}

Underlying data

Harvard dataverse: Sea grapes extract effect on blood glucose level (BGL), total cholesterol (TC), and serum PGC-1 $\alpha$ concentrations. 
DOI: https://doi.org/10.7910/DVN/8IKREA (Nurkolis, 2021).

The project contains the following underlying data:

- Raw data for the sea grapes extract effect on blood glucose level (BGL), total cholesterol (TC), and serum PGC- $1 \alpha$ concentrations.

\section{Reporting guidelines}

Harvard Dataverse: Arrive checklist for Sea grapes extract with blood glucose, total cholesterol, and PGC-1 $\alpha$ in rats fed on cholesterol- and fat-enriched diet.

https://doi.org/10.7910/DVN/NXF0IW (Nurkolis et al., 2021).

Data are available under the terms of the Creative Commons Zero "No rights reserved" data waiver (CC0 1.0 Public domain dedication).

\section{Author contributions}

M.K and F.N. collated study ideas, designed and experiment, analyzed data, and compiled manuscripts. N.A.T, N. R, N. S, H.K.P, D.S.W and N. M analyzed and interpreted the data and critically revised the manuscript. F. N and F.M.I conducted experiments, analyzed biochemistry, and critically revised the manuscript. N. M, M.R.B, R. R, P.S.A and K.E.K.M, implemented experimental protocols, assisted in statistical analysis, interpreted data, and critically revised manuscripts. All writers read and approve the final manuscript.

\section{Acknowledgment}

We thank all contributors for their outstanding help in formatting the paper. I would also like to express my gratitude to Prof. Ir. Hardinsyah, MS., Ph.D. (as President of the Federations of Asian Nutrition Societies; President of the Food and Nutrition Society of Indonesia; and Chair of Southeast Asia Probiotics Scientific and Regulatory Experts Network), who has provided comments, suggestions, and input in the research and writing of this paper, as well as the motivation to keep the passion for research during the pandemic.

\footnotetext{
References

Anantharaju A, Feller A, Chedid A: Aging Liver. A review. Gerontology. 2002 Nov Dec; 48(6): 343-353.

PubMed Abstract | Publisher Full Text

Birben E, Sahiner UM, Sackesen C, et al.: Oxidative stress and antioxidant defense. World Allergy Organ J. 2012; 5(1): 9-19.

PubMed Abstract | Publisher Full Text | Free Full Text

Bugianesi E, McCullough AJ, Marchesini G: Insulin resistance: $\mathbf{A}$ metabolic pathway to chronic liver disease. Hepatology. 2005; 42 987-1000.

PubMed Abstract | Publisher Full Text

Chen $X$, Sun $Y$, Liu $H$, et al.: Advances in cultivation, wastewater treatment application, bioactive components of Caulerpa lentillifera and their biotechnological applications. Peer J. 2019 Jan 8; 7: e6118. PubMed Abstract | Publisher Full Text | Free Full Text

Clandinin MT, Cook SL, Konard SD, et al.: The effect of palmitic acid on lipoprotein cholesterol levels. Int J Food Sci Nutr. 2000; 51(sup1): s61-s71. PubMed Abstract

Facchini FS, Hua N, Abbasi F, et al.: Insulin resistance as a predictor of agerelated diseases. J Clin Endocrinol Metab. 2001; 86: 3574-3578. PubMed Abstract | Publisher Full Text

Freitas I, Boncompagni E, Tarantola $E$, et al.: In situ evaluation of oxidative stress in rat fatty liver induced by a methionine- and choline-deficient diet. Oxid. Med. Cell Longev. 2016; 2016: 9307064 PubMed Abstract | Publisher Full Text | Free Full Text

Hancock JT, Desikan R, Neill SJ: Role of Reactive Oxygen Species in Cell Signaling Pathways. Biochem Biomed Asp Oxi Modifi. 2001; 29(2): 345-350.

PubMed Abstract | Publisher Full Text

Harb AA, Bustanji YK, Abdalla SS: Hypocholesterolemic effect of $\beta$ caryophyllene in rats fed cholesterol and fat enriched diet. J Clin

Biochem Nutr. 2018; 62(3): 230-237.

PubMed Abstract | Publisher Full Text | Free Full Text

St-Pierre J, Drori S, Uldry M, et al.: Suppression of reactive oxygen species and neurodegeneration by the PGC-1 transcriptional coactivators.

Cell. 2006; 127(2): 397-408.

PubMed Abstract | Publisher Full Text

Kang NE, Kim JH, Lee YK, et al.: A study of consumers' perceptions and prediction of consumption patterns for generic health functional foods. Nutr Res Pract. 2011; 5(4): 313-321.

PubMed Abstract | Publisher Full Text | Free Full Text

Khani M, Motamedi P, Dehkhoda MR, et al.: Effect of thyme extract supplementation on lipid peroxidation, antioxidant capacity, PGC-1a content and endurance exercise performance in rats. J Int Soc Sports Nutr. 2017; 14(1): 1-8.

PubMed Abstract | Publisher Full Text | Free Full Text

Liang H, Ward WF: PGC-1a: A key regulator of energy metabolism. AmJ Physiol - Adv Physiol Educ. 2006; 30(4): 145-151. American Physiological Society.

PubMed Abstract | Publisher Full Text

Liguori I, Russo G, Curcio F, et al.: Oxidative stress, aging, and diseases. Clinical Interventions in Aging. Dove Medical Press Ltd; 2018; (Vol. 13, pp. 757-772)

PubMed Abstract | Publisher Full Text | Free Full Text

Manna P, Das J, Ghosh J, et al.: Contribution of type 1 diabetes to rat liver dysfunction and cellular damage via activation of NOS, PARP, IкB $\alpha /$ NF-KB, MAPKs, and mitochondria-dependent pathways: Prophylactic role of arjunolic acid. Free Radic. Biol. Med. 2010; 48: 1465-1484.

PubMed Abstract | Publisher Full Text

Meigs JB, Muller DC, Nathan DM, et al.: The Natural history of progression from normal glucose tolerance to type 2 diabetes in the
} 
Baltimore longitudinal study of aging. Diabetes. 2003; 52: 1475-1484. PubMed Abstract | Publisher Full Text

Mensink RP: Fatty acids: Health effects of saturated fatty acids. 2013. Miller NE: Why does plasma low density lipoprotein concentration in adults increase with age? Lancet. 1984 Feb 4; 1(8371): 263-267.

PubMed Abstract | Publisher Full Text

Nurkolis, et al.: Arrive Guidelines Checklist for Sea grapes extract with blood glucose, total cholesterol, and PGC-1a in rats fed on cholesteroland fat-enriched diet. Harvard Dataverse. V1. 2021a.

Publisher Full Text

Nurkolis F: RAW Data for Detailed information of in vivo experiment of sea grapes extract activity against blood glucose level (BGL), tota

cholesterol (TC), and serum PGC-1a concentration. Harvard Dataverse. V1. UNF:6:mUkIz8gcaJrTy1jSEfpewA== [fileUNF]. 2021.

Publisher Full Text

Nurkolis F, Mantik KEK, Kuswari M, et al.: Sea Grape (Ceulerpa racemosa) Cereal with Addition of Tempe as an Anti-Aging Functional Food: in vitro Study. Curr Devel Nutri. 2021b; 5(Supplement_2): 41-41. Publisher Full Text

Pakki E, Tayeb R, Usmar U, et al.: Effect of orally administered combination of Caulerpa racemosa and Eleutherine americana (Aubl) Merr extracts on phagocytic activity of macrophage. Res Pharm Sci. 2020; 15(4): 401-409.

PubMed Abstract | Publisher Full Text | Free Full Text Palsamy P, Sivakumar S, Subramanian S: Resveratrol attenuates hyperglycemia-mediated oxidative stress, proinflammatory cytokines and protects hepatocytes ultrastructure in streptozotocinnicotinamide-induced experimental diabetic rats. Chem. Biol. Interact. 2010; 186: 200-210.

PubMed Abstract | Publisher Full Text

Park S: The effects of high concentrations of vitamin C on cancer cells. Nutrients. MDPI AG; 2013; (Vol. 5, Issue 9, pp. 3496-3505). PubMed Abstract | Publisher Full Text | Free Full Text

Park S, Han SS, Park CH, et al.: L-Ascorbic acid induces apoptosis in acute myeloid leukemia cells via hydrogen peroxide-mediated mechanisms. Int J Biochem Cell Biol. 2004; 36(11): 2180-2195. PubMed Abstract | Publisher Full Text

Pizzino G, Irrera N, Cucinotta M, et al.: Oxidative Stress: Harms and Benefits for Human Health. Oxid Med Cell Longev. 2017; 2017 PubMed Abstract | Publisher Full Text | Free Full Text
Puigserver $P$, Spiegelman BM: Peroxisome proliferator-activated receptor- $\gamma$ coactivator $1 \alpha$ (PGC-1 $\alpha$ ): Transcriptional coactivator and metabolic regulator. Endocr Rev. 2003; 24(1): 78-90.

PubMed Abstract | Publisher Full Text

Qudus B Aroyehun A, Abdul Razak S, Palaniveloo K, et al.: Bioprospecting Cultivated Tropical Green Algae, Caulerpa racemosa (Forsskal)

J. Agardh: A Perspective on Nutritional Properties, Antioxidative

Capacity and Anti-Diabetic Potential. Foods. 2020; 9(9): 1313.

PubMed Abstract | Publisher Full Text | Free Full Text

Baldelli S, Aquilano K, Ciriolo MR: PGC-1 $\alpha$ buffers ROS-mediated removal of mitochondria during myogenesis. Cell Death Dis. 2014; 5(11): e1515.

PubMed Abstract | Publisher Full Text | Free Full Text

Sies $\mathrm{H}$, Jones DP: Reactive oxygen species (ROS) as pleiotropic physiological signalling agents. Nat Rev Mol Cell Biol. 2020; 21(7):

363-383.

PubMed Abstract | Publisher Full Text

Tanna B, Yadav S, Mishra A: Anti-proliferative and ROS-inhibitory activities reveal the anticancer potential of Caulerpa species. Mol Biol Rep. 2020; 47(10): 7403-7411.

PubMed Abstract | Publisher Full Text

Taslim NA, Nurkolis F: Probiotic Drink Banana with Addition of Sea Grapes Flour (Caulerpa racemosa) Rich in Polyphenols and Dietary Fiber as Functional Food Potential Anti-NCDs. Annals Romanian Society Cell Biol. 2021; 25(6): 6500-6504.

Yang P, Liu DQ, Liang TJ, et al.: Bioactive constituents

from the green alga Caulerpa racemosa. Bioorg Med Chem

2015; 23(1): 38-45.

PubMed Abstract | Publisher Full Text

Yang S, Loro E, Wada S, et al.: Functional effects of muscle PGC-1alpha in aged animals. Skeletal Muscle. 2020; 10(1): 1-8.

PubMed Abstract | Publisher Full Text | Free Full Text

Yap WF, Tay V, Tan SH, et al.: Decoding antioxidant and antibacterial potentials of Malaysian green seaweeds: Caulerpa racemosa and

Caulerpa lentillifera. Antibiotics. 2019; 8(3).

PubMed Abstract | Publisher Full Text | Free Full Text

Zhang YJ, Gan RY, Li S, et al.: Antioxidant phytochemicals for the prevention and treatment of chronic diseases. Molecules. MDPI AG; 2015; (Vol. 20, Issue 12, pp. 21138-21156)

PubMed Abstract | Publisher Full Text | Free Full Text 


\section{Open Peer Review}

\section{Current Peer Review Status: ?}

\section{Version 1}

Reviewer Report 20 August 2021

https://doi.org/10.5256/f1000research.58483.r90945

(C) 2021 Kairupan C. This is an open access peer review report distributed under the terms of the Creative Commons Attribution License, which permits unrestricted use, distribution, and reproduction in any medium, provided the original work is properly cited.

\section{Carla F. Kairupan}

Bagian Patologi Anatomi Fakultas Kedokteran, Universitas Sam Ratulangi, Manado, Indonesia Update Note, 4th February 2022:

A COI statement has been added detailing a shared affiliation between author and reviewer, which was not declared at the time of the publishing of this report. The COI statement is below.

This is an interesting research, in which the treatment with Sea grapes extract clearly improved blood glucose levels, total cholesterol, and PGC-1a in rats. However, it is not the first study that is done on the beneficial effects of Sea grapes extract.

The paper is well written and the experimental design is set up well, however, the statistical analysis should be better described.

The following points should also be addressed appropriately in the revision.

1. The Laboratory of Pharmacology, Faculty of Mathematics and Natural Sciences, Sam Ratulangi University where the study was conducted is not in Makassar.

2. The terminology and composition of diets are inconsistent and unclear.

3. The area where the blood sample was collected is inappropriate.

4. The doses of Sea grapes extract were $150 \mathrm{mg} / \mathrm{kg} \mathrm{BW}$ and $450 \mathrm{mg} / \mathrm{kg} \mathrm{BW}$. How did you decide on these doses? Are there any safety issues?

The article may also benefit from an English language edit.

Is the work clearly and accurately presented and does it cite the current literature? Yes 
Is the study design appropriate and is the work technically sound?

Yes

Are sufficient details of methods and analysis provided to allow replication by others? Yes

If applicable, is the statistical analysis and its interpretation appropriate?

Yes

Are all the source data underlying the results available to ensure full reproducibility? Yes

Are the conclusions drawn adequately supported by the results? Yes

Competing Interests: I share an affiliation with some of the authors of this article: Sam Ratulangi University. I confirm that this has not affected my ability to provide an unbiased and impartial review for this article.

Reviewer Expertise: Pathology, Moleculer Genetics, Herbal Medicine

I confirm that I have read this submission and believe that I have an appropriate level of expertise to confirm that it is of an acceptable scientific standard, however I have significant reservations, as outlined above.

Author Response 31 Aug 2021

Fahrul Nurkolis

Dear Dr. Carla F Kairupan, PhD.,

Thank you for the appreciation and constructive review comments to improve this paper.

We have made minor improvements as you mentioned in the review, as follows:

1. The Laboratory of Pharmacology, Faculty of Mathematics and Natural Sciences, Sam Ratulangi University where the study was conducted is not in Makassar, it should be a typo and we have changed it to Manado.

2. The terminology and composition of diets are inconsistent and unclear. We've made it clear.

3. The area where the blood sample was collected is inappropriate.

We've made that clear, in the tail of the rats.

4. The doses of Sea grapes extract were $150 \mathrm{mg} / \mathrm{kg} \mathrm{BW}$ and $450 \mathrm{mg} / \mathrm{kg} \mathrm{BW}$. How did you decide on these doses? Are there any safety issues? In existing studies, most use $100 \mathbf{~ m g}$ and $200 \mathrm{mg}$, therefore the choice of this dose is higher and different from previous 
studies and $\mathbf{4 5 0}$ is the maximum capacity for a safe rats stomach.

Thank you,

Greetings, hope you are well!

Competing Interests: No competing interests were disclosed.

The benefits of publishing with F1000Research:

- Your article is published within days, with no editorial bias

- You can publish traditional articles, null/negative results, case reports, data notes and more

- The peer review process is transparent and collaborative

- Your article is indexed in PubMed after passing peer review

- Dedicated customer support at every stage

For pre-submission enquiries, contact research@f1000.com 